\title{
LONG TERM BEACH EROSION: MORPHODYNAMIC CASE STUDY IN MONT-ROIG BEACH, SPAIN
}

\author{
Jordi Galofré1, Dolores Ortiz² and Raúl Medina ${ }^{3}$
}

\begin{abstract}
Long term coastal erosion in beaches induced by long-shore sediment transport is an important aspect to be taken account in beach behavior. If anthropogenic impacts in coastal stretch (harbor, detached breakwaters, lack of sediments from streams and gullies, and urban pressure) interrupting long-shore currents and transport and decreasing sediment supply, the coastal equilibrium disappears. In this paper a case study is shown in order to analyze long term beach behavior in a coastal stretch affected by erosion. After a brief description of morphological aspects, causes and effects that have incidence on the case study area will be shown. General background and coastal works are detailed. The ideas based on a classical analysis of beach behavior are exposed and results obtained from bathymetric analysis and numerical models are showed. Morphology, wave climate, morphodynamics and sediment budget are evaluated and morphodynamic beach behavior is proposed. A diagnosis is made and mitigation proposal for coastal erosion will be proposed.
\end{abstract}

Keywords: wave climate; morphodynamics; sediment budget

\section{INTROCUCTION}

The objective of this paper is to study long term beach erosion problems using morphodynamic evolution analysis applied to Mont-roig del Camp, Spain, beaches case study. The paper analyzes the coastal stretch aerial pictures, 1956 to 2008, and bathymetric surveys, 1994 to 2009, focusing on long term beaches erosion problems and suggesting some solutions in order to guarantee beach functionality: protection, leisure and environment. By means of field data, aerial picture data and numerical models a wide aspect of morphodynamic evolution analysis will be made applied to a case study. The study includes shoreline evolution, plan form analysis, beach profile analysis, evaluation of wave refraction, diffraction and height modifications, determination of wave induced currents and estimation of beach modal states. Conclusion of beach behavior will be reach and future plans will be proposed in order to maintain the role of the beach.

\section{CASE STUDY}

\section{Morphological Description}

The stretch of coast analyzed in this study is located in Mont-roig del Camp. It is a municipality in the north-east of Spain, in Catalonian Autonomous Community, in the border of the Mediterranean Sea. It is placed about $150 \mathrm{~km}$ south of Barcelona and $50 \mathrm{~km}$ south of Tarragona. In this paper the coastal analysis is focused on $10 \mathrm{~km}$ from Cambrils harbor to the south, see figure 1.

Morphological features in this area are Cambrils harbour, built in the 1940's, Riudecanyes Gully, Pixerota Gully, Porquerola Gully, and Gelat Marsh. Cambrils harbour is a total barrier to the litoral drift from the east to the west. The cells than can be divided the coast are: Cambrils harbour to Riudecanyes Gully,3.2 km, Riudecanyes Gully to Pixerota Gully, $2.0 \mathrm{~km}$, and Pixerota Gully to Gelat Marsh, $4.8 \mathrm{~km}$.

Sediment supply from streams and gullies has been decreasing during last decades as a consequence of sand mining from the basin, embanking, and regulations of flume.

Urban pressure in this area has been increasing during last decades causing acceleration in erosive effects. Lack of buffer areas in this stretch is extremely dangerous in erosion processes. In figure 2, main morphological features are showed. This stretch is located between Tortosa and Salou capes. The influence wave area is limited from Tortosa cape to Llobregat delta in the north near Barcelona area.

\footnotetext{
${ }^{1}$ Directorate of Coastal and Sea Sustainability, MAGRAMA, PI Imperial Tarraco 4-4 FI, Tarragona, 43005, Spain

2 Directorate of Coastal and Sea Sustainability, MAGRAMA, PI San Juan de la Cruz s/n, Madrid, 28071, Spain

${ }^{3}$ Instituto de Hidráulica Ambiental "IH Cantabria", Parque Científico y Tecnológico de Cantabria, c/ Isabel Torres 15, Santander, 39011, Spain
} 


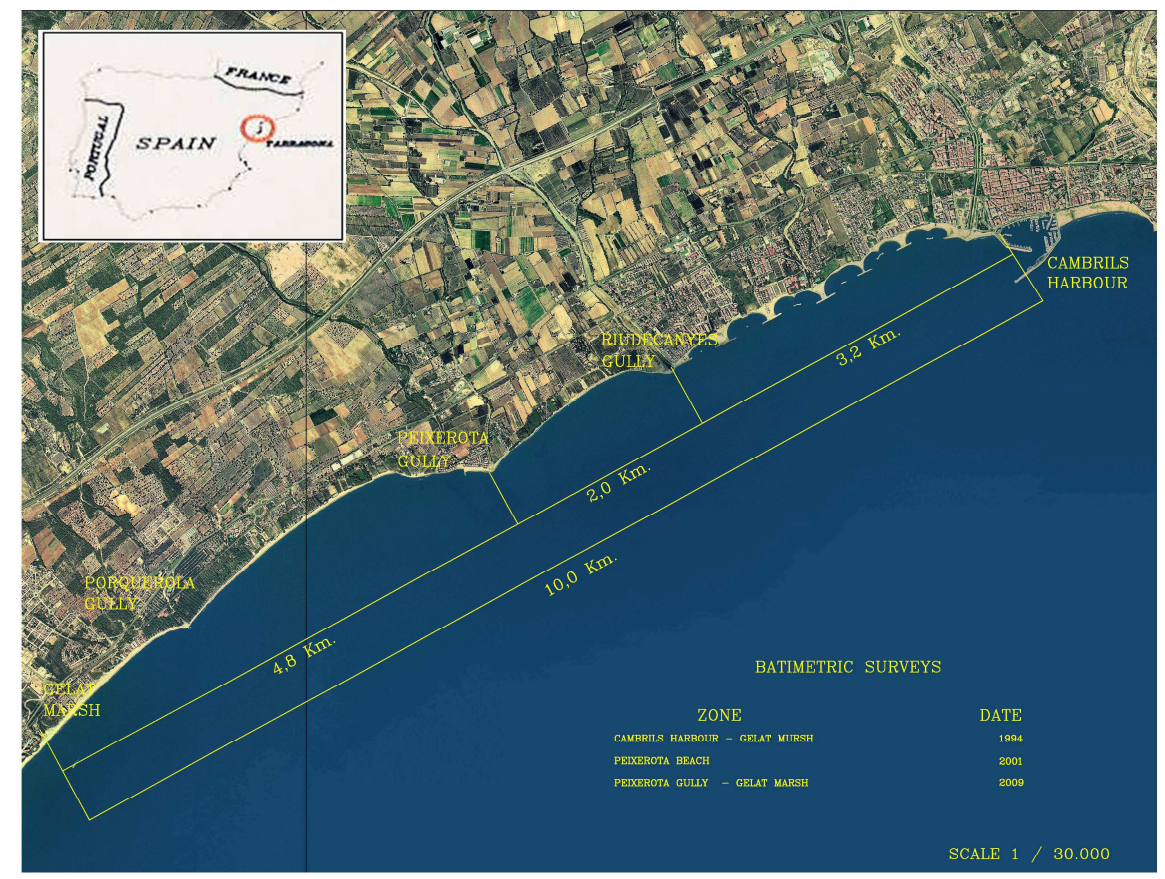

Figure1.- Location Map

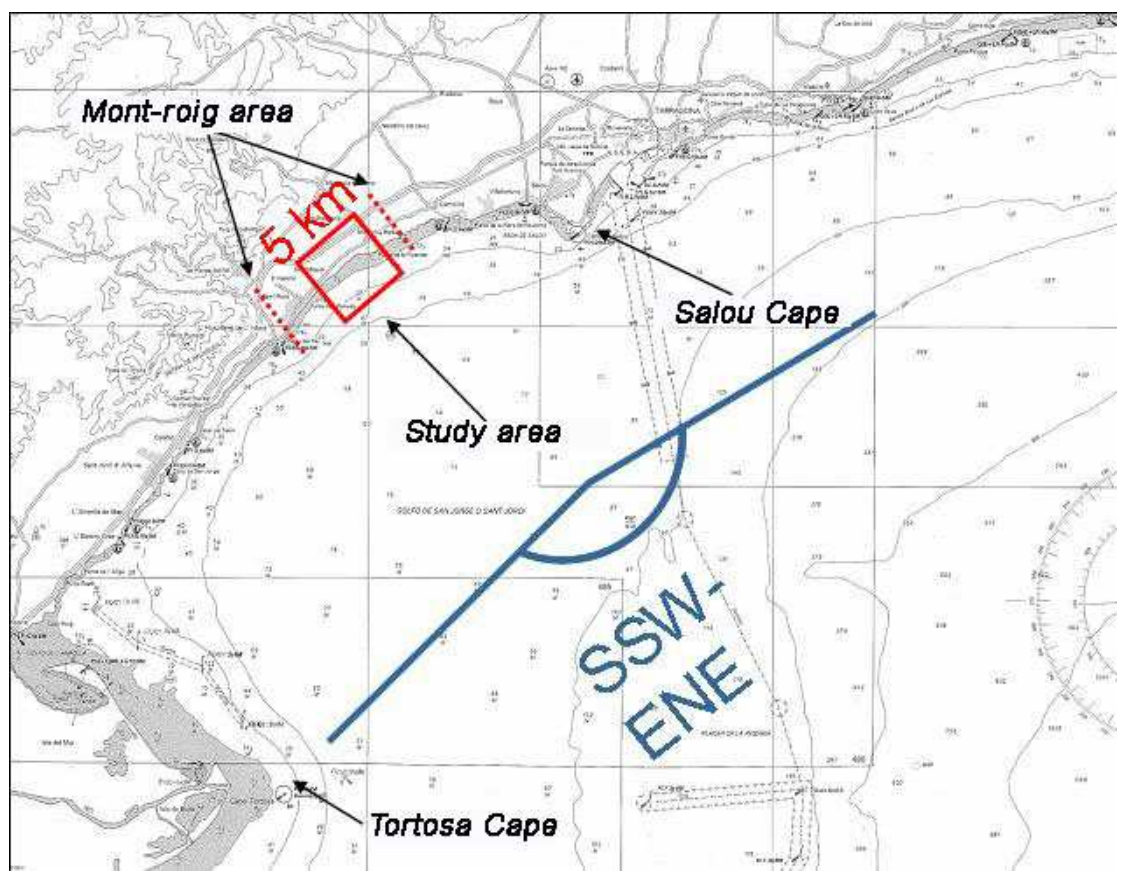

Figure 2.- Morphological features 


\section{Historical Evolution}

The stretch, that has been defined previously reach, $10 \mathrm{~km}$. physiographic unit. From east toe west different structures have been built during the last half century. In the 1940-50's a harbor was built in front of Cambrils old fisherman buildings, this structure interrupts longshore transport from the $\mathrm{E}$ to the W. Erosion problems appear downstream of it. To mitigate this phenomena several detached breakwaters were designed and constructed (4 in 1977-78 and 2 in 1986-87) and shadow areas were filled with sand. In the 90's erosion problems appear downstream until now, in figure 3 shoreline evolution is shown taking account different profiles,

Bathymetric surveys in this area have been carried out: 1994, 2001, and 2009, in order to analyze morphological changes in emerged and submerged beach and shoreline evolution, in figure 4 bathymetric survey from 2009 is shown. Some aerial pictures have been obtained from 1956, 1980, 1985, 1986, 1990, 2001, 2002, 2004, 2006, and 2008 and used in this study. Nautical maps from Marine Hydrographic Institute, 1961 and 1980, have been incorporate in data base.
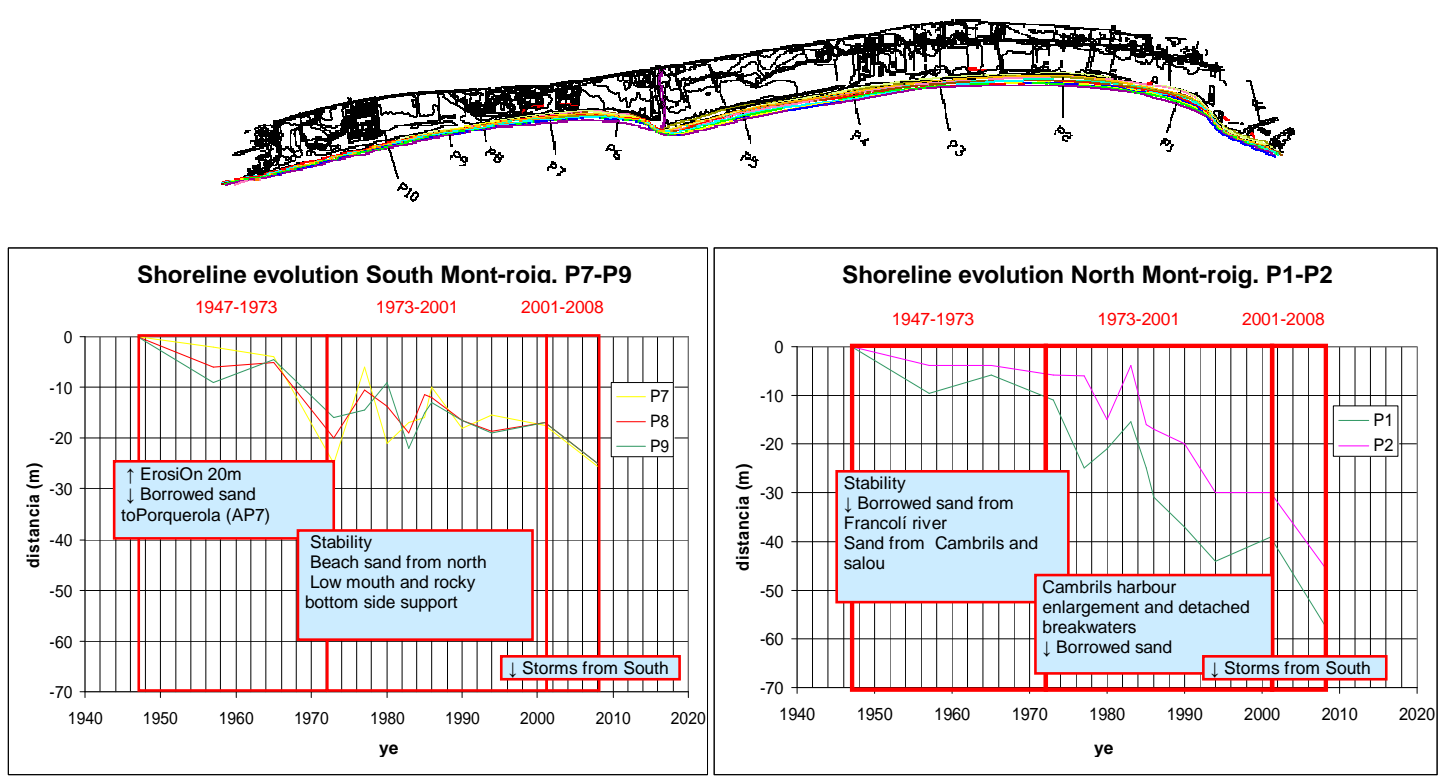

Figure3.- Shoreline evolution

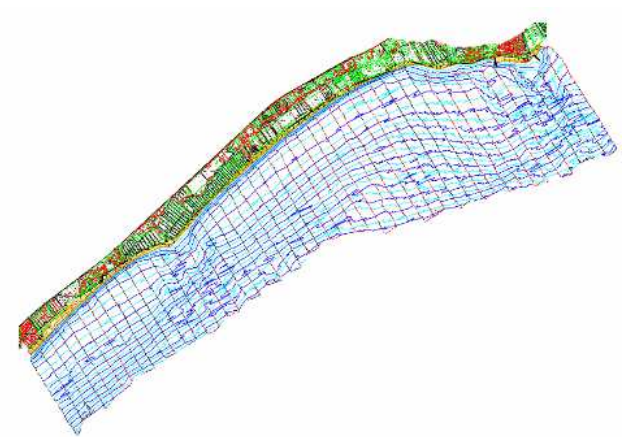

Figure 4.- Bathymetric survey 2009 


\section{Wave Climate}

The site is characterized by two predominant directions of wave approach, E and S. More then three quarters of the deep water waves approach Mont-roig del Camp beaches from these directions. The annual significant wave is about $0.5 \mathrm{~m}$ with typical winter storm of $\mathrm{H}_{\mathrm{s}}$ about $3.0 \mathrm{~m}$, tides negligible, see figure 5 .
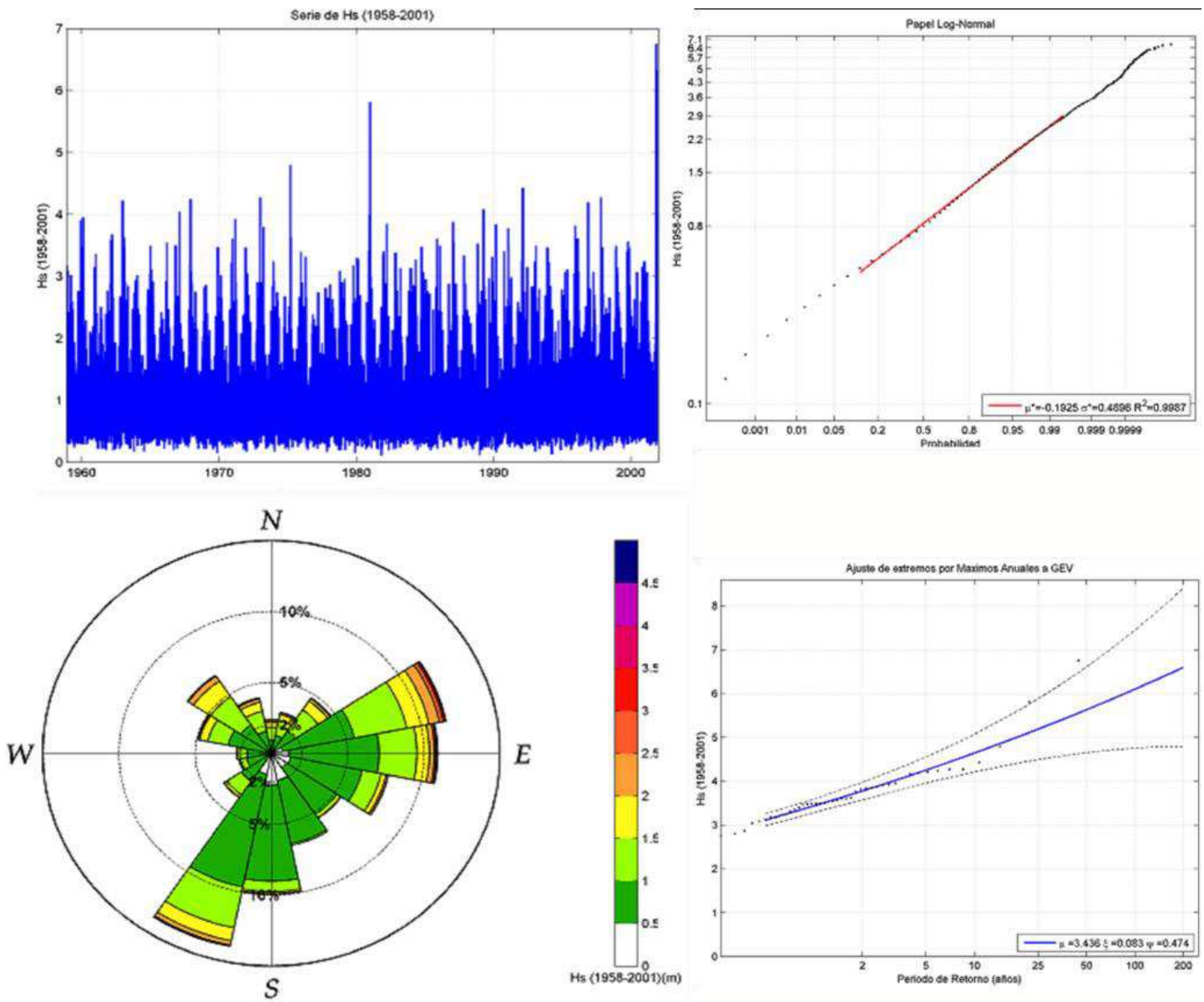

Figure 5.- Wave rose, record, and $\mathrm{H}_{\mathrm{S}}$ regime

ENE and SSW waves diffraction produced by Salou and Tortosa capes decrease the energy that reach beaches with $\mathrm{H}_{\mathrm{S}}<1 \mathrm{~m}$ in medium annual storm. SE and SSE waves that reach the coast are greater than the other ones, but they have less probability of occurrence. They have not so much incidence on total dynamics.

ENE and SSW depth water waves only generate significant currents E and S waves. E and ESE generate longshore currents to the S, see figure 6a. SE, SSE and S waves generate longshore currents tom the $\mathrm{N}$, except on Porquerola gully mouth, see figure 6b. Rocky submerged low bottom on Porquerola gully mouth diffract SE, SSE and S waves and increase wave height. Vortex effects, when waves reach this area from the middle of the mouth, on storm events generate longshore currents diverging to the $\mathrm{N}$ and $\mathrm{S}$.

These two wave groups have similar probability of occurrence, but they have different magnitude. SE, SSE and $\mathrm{S}$ waves generates longshore currents to the $\mathrm{N}$, only $1 \% \mathrm{H}_{\mathrm{S}}>1 \mathrm{~m}$ (depth water waves). $\mathrm{H}_{\mathrm{S}}$ maximum reach about $1.5 \mathrm{~m}$ from SE and ESE waves, and $2.5 \mathrm{~m}$ from S. E and ESE waves reach $\mathrm{H}_{\mathrm{S}}$ maximum about $4 \mathrm{~m}$. The percentage of occurrence is about $7 \%$ in waves with $\mathrm{H}_{\mathrm{S}}>1 \mathrm{~m}$ on depth water.

It can be summarize that waves that generate longshore currents, in this stretch, to the $\mathrm{N}$ and to the $\mathrm{S}$ are similar. In storm conditions, waves that generate longshore currents to the south are dominant. 

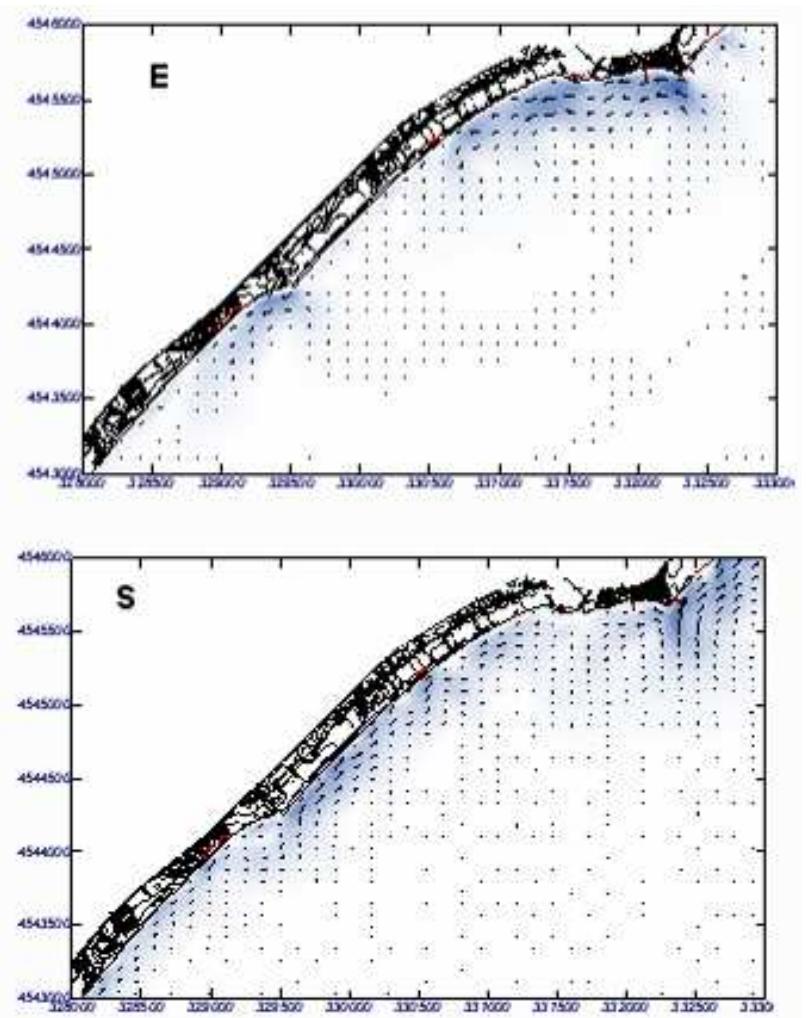

Figure 6.- Longshore currents generate from $E(a)$ and $S$ (b) waves

\section{Morphodynamics}

In this section profile and planform analysis, sediment budget and morphodynamic model behavior will be shown. First of all a description of sand, native and borrow, will be made in order to understand beach behavior and possible solutions in the future.

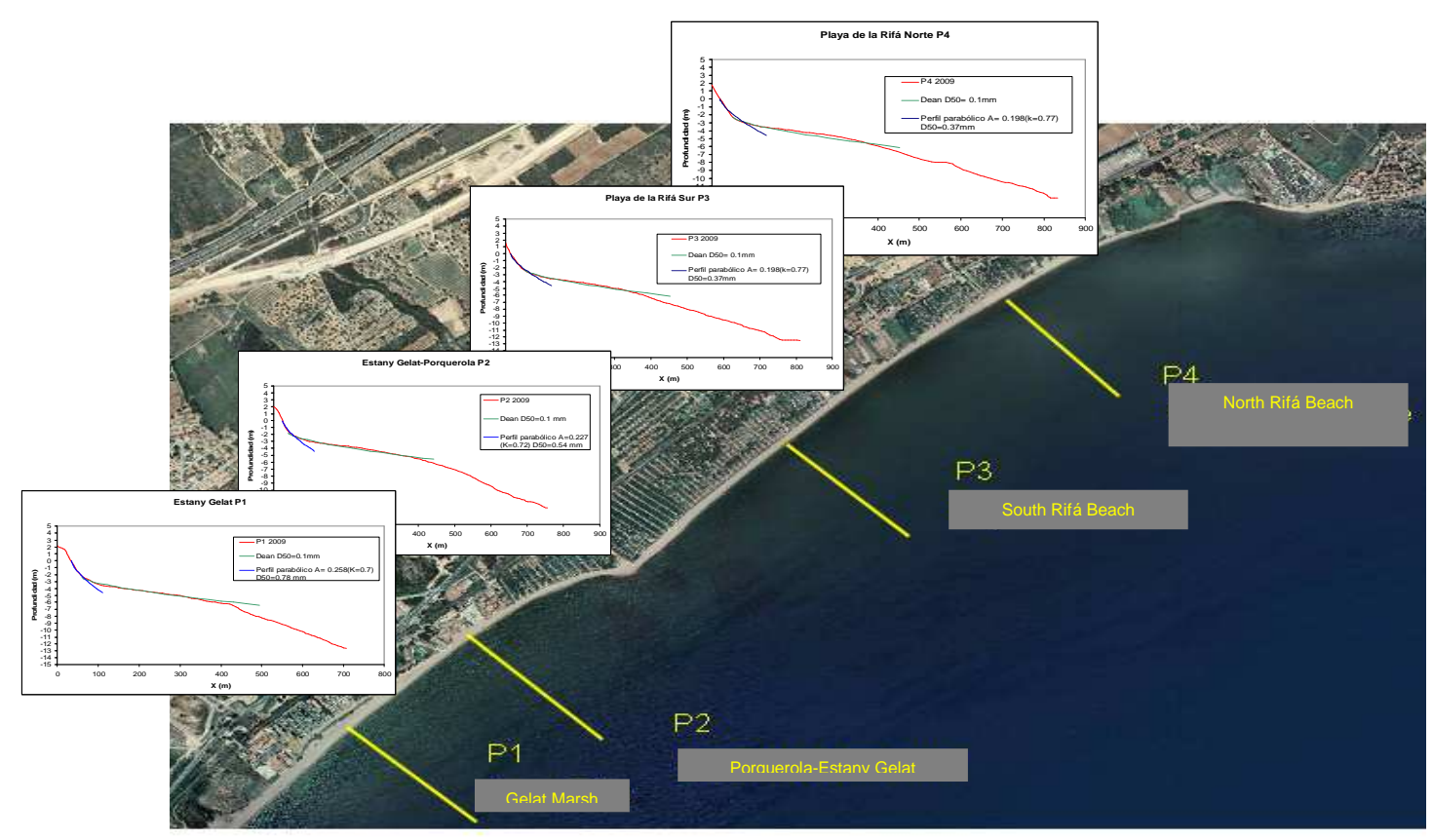

Figure 7.- Beach profile analysis 
According with bathymetric survey (2009), where sand samples were obtained and analyzed, the sand of these beaches has a range from $\mathrm{D}_{50}=0.8 \mathrm{~mm}$ to $0.3 \mathrm{~mm}$ in emerged beach, and $\mathrm{D}_{50}=0.3 \mathrm{~mm}$ to $0.1 \mathrm{~mm}$ in submerged beach. If some filling or nourishment work are required, in the future, some sand borrow bank were located near the stretch. The total amount of borrow sand storage volume (1993) is about $2,000,000 \mathrm{~m}^{3}$. The sand composite has a range $\mathrm{D}_{50}=0.34 \mathrm{~mm}$ to $0.74 \mathrm{~mm}$ with an average of $\mathrm{D}_{50}=0.46 \mathrm{~mm}$.

Profile analysis is made in different sections of the beaches, see figure 7. As a general rule it can be inferred that:

- $\quad$ Closure depth reach about $\mathrm{h} \approx \approx 6.5 \mathrm{~m}$.

- The profile has a step changing the slope of profile at bathymetric $-2 \mathrm{~m}$ to $-3 \mathrm{~m}$. First step is approached by Dean profile with $\mathrm{D}_{50}=0.37 \mathrm{~mm}$ to $0.78 \mathrm{~mm}$, second one with $\mathrm{D}_{50}=0.1 \mathrm{~mm}$ in all cases.

- A platform from $300 \mathrm{~m}$ to $500 \mathrm{~m}$ appears from step change, energy dissipation is produced in this area.

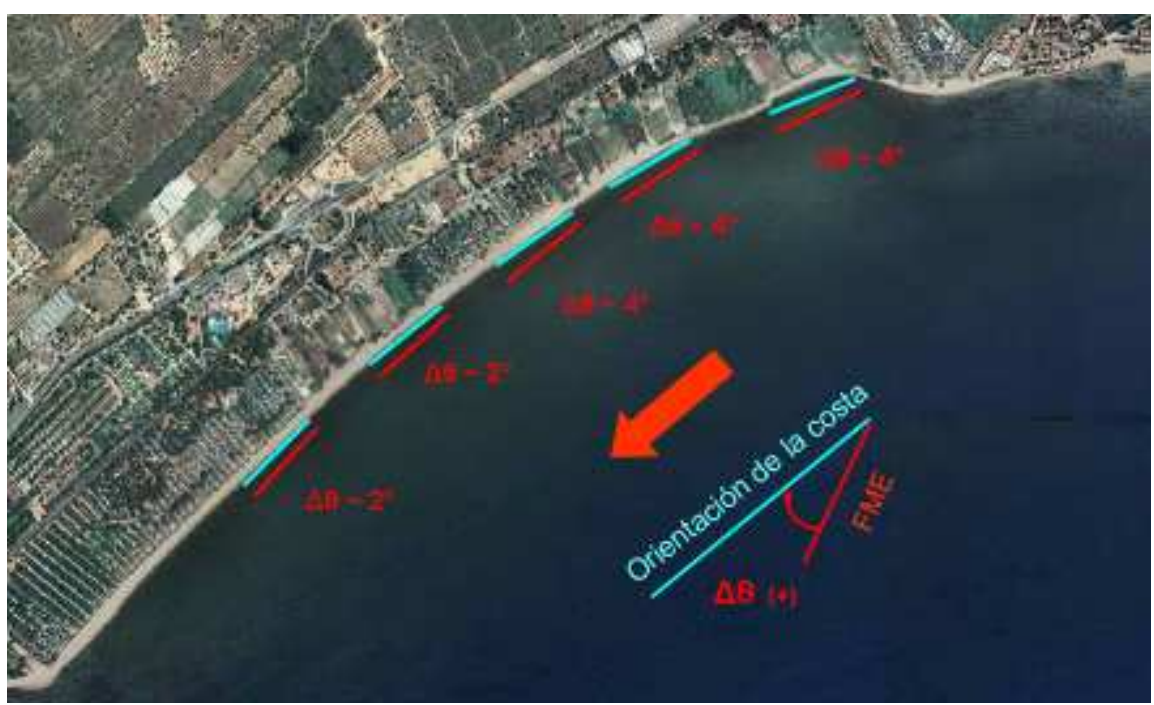

Figure 8.- Shoreline and energy medium flux orientation differences

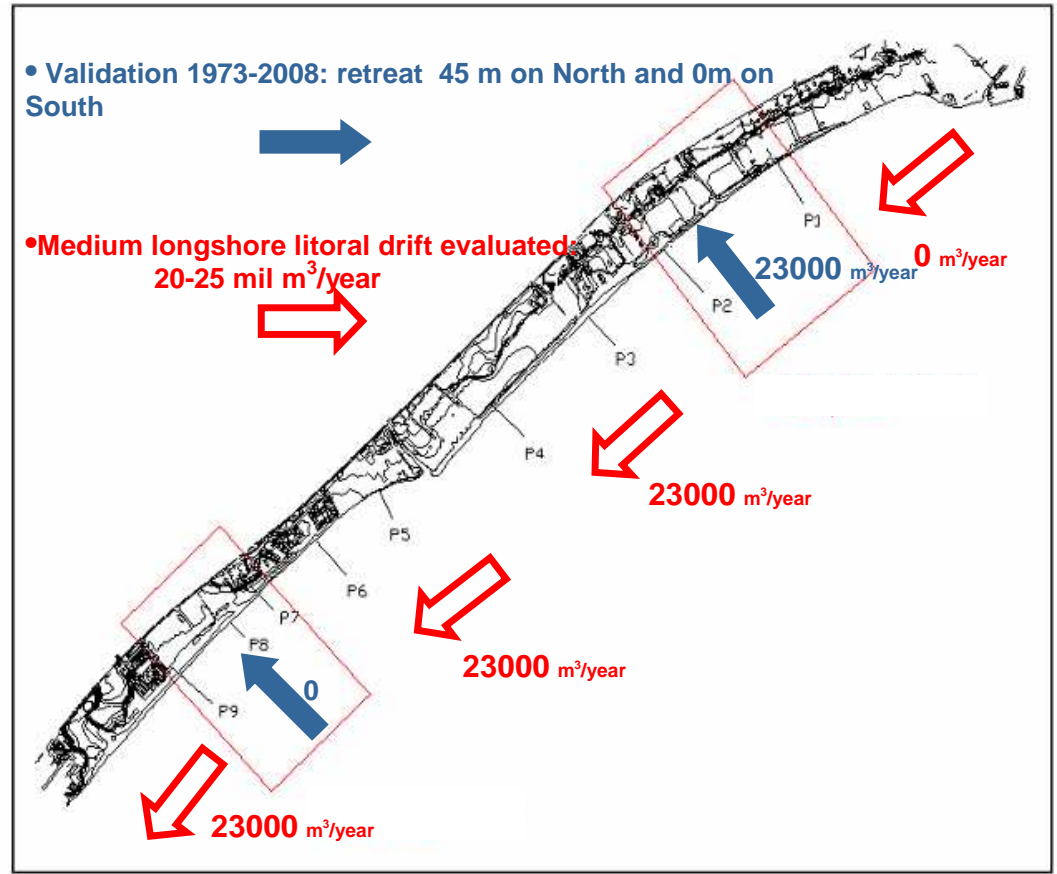

Figure 9.- Morphodynamic beach model behavior 
Planform evolution along the time is a consequence of the different orientation between shoreline position and energy medium flux (EMF), see figure 8 . There is an angle between shoreline position and EMF that generate non equilibrium beaches and induce longshore drift to the south. Longshore littoral transport has a great variability. In order to compare it, shoreline positions have been compared from 1973 to 2008. There is $45 \mathrm{~m}$ retreat on the north and $0 \mathrm{~m}$ on the south. Medium longshore littoral transport has been evaluated about 20,000 $\mathrm{m}^{3} /$ year $-25,000 \mathrm{~m}^{3} /$ year. Morphodynamic beach model behavior is shown in figure 9.

Rifà - Porquerola stretch is loosing native sediment, 20,000 $\mathrm{m}^{3} /$ year, without sand input. This $20,000 \mathrm{~m}^{3} /$ year are an input to Porquerola - Rifà south. There is a longshore transport from north to south that it is constrained by a rocky spit, like a groin, that reduces beach retreat in this area. The rocky spit allows to by-pass sediment to the south area, it retains sediment from waves that generate currents from the south to the north. Net sediment transport at this point is negligible.

When longshore currents are driven to the north, they are reduced on Porquerola Gully Spit. The final effect is that sand available in this stretch is distributed along the coast according wave direction. Accumulation and erosion processes and effects appear in these periods. The sediment lost during East storms is not recovered.

\section{Alternatives}

Several alternatives have been analyzed in order to maintain beach functionality. The alternatives reach a wide range of proposals from natural beach evolution, maintaining present beach shape, stabilization with hard structures (groins and detached breakwater), sand filling, and different combinations. The different alternative analyzed are:

A1: Natural beach evolution to reach new equilibrium position.

A2: Present beach shape, upkeep plan with periodical sand fill.

A3: Beach restoration with two groins and sand filling.

A4: Beach restoration with one groin, one detached breakwater (tombolo), and sand filling.

A5: Beach restoration with one groin, one detached breakwater (spit), and sand filling.

Alternative A1: Natural beach evolution to reach new equilibrium position means no action. In this case no hard structures and fill volume need to stabilize the coast is null. Shoreline retreat in Rifa beach is about $145 \mathrm{~m}$ and south of Porquerola spit $160 \mathrm{~m}$. In the south of the stretch, at the beginning of cliff area, there is a fixed point. See figure 10 for details.

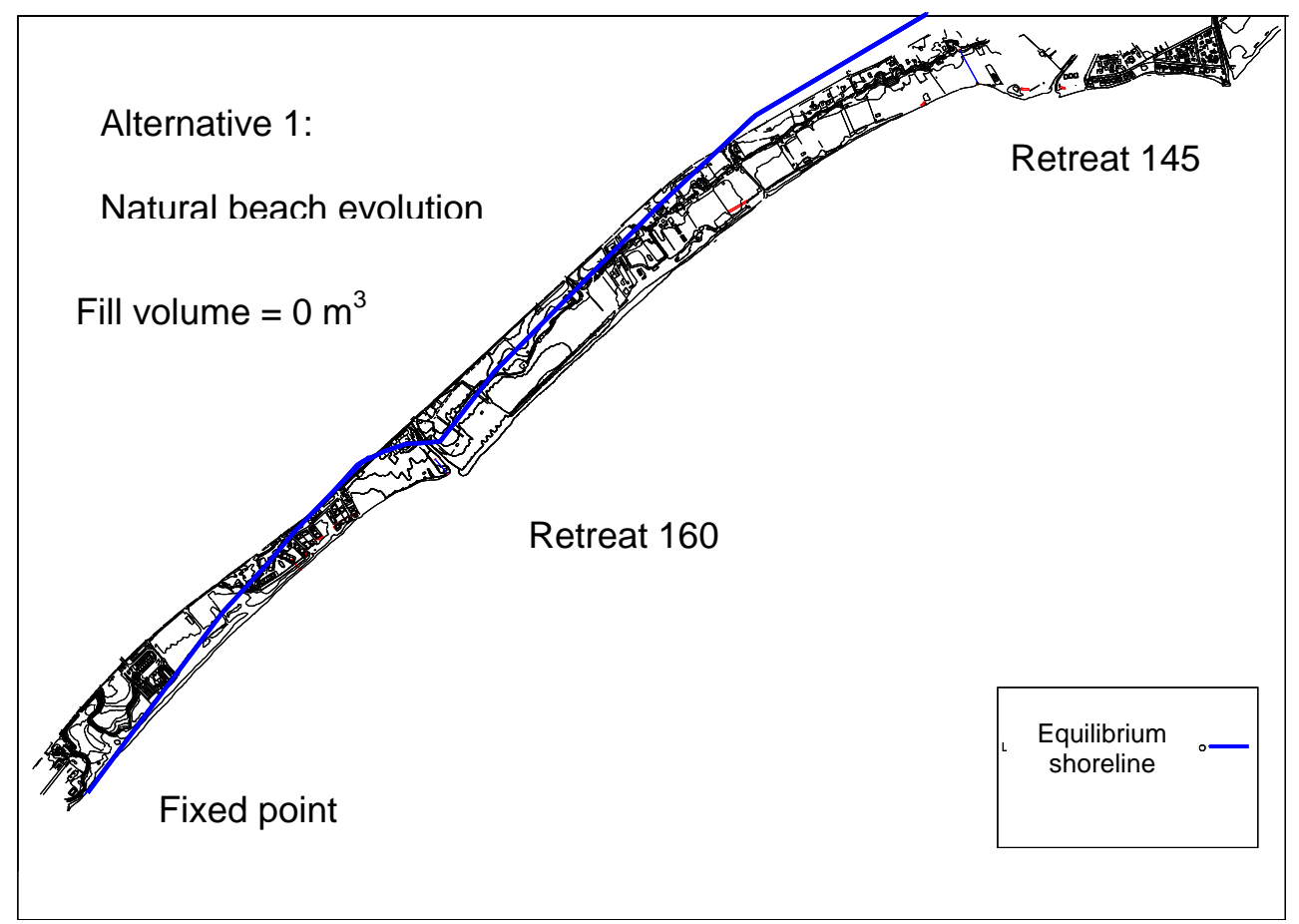

Figure 10.- Alternative A1: Natural beach evolution to reach new equilibrium position 
Alternative A2: Present beach shape, upkeep plan with periodical sand fill needs periodical sand fill in order to upkeep the present shoreline. It is a soft philosophy in beach protection strategy. In figure 11 a fill frequency and nourishment volume required is shown for maintain present beach shape

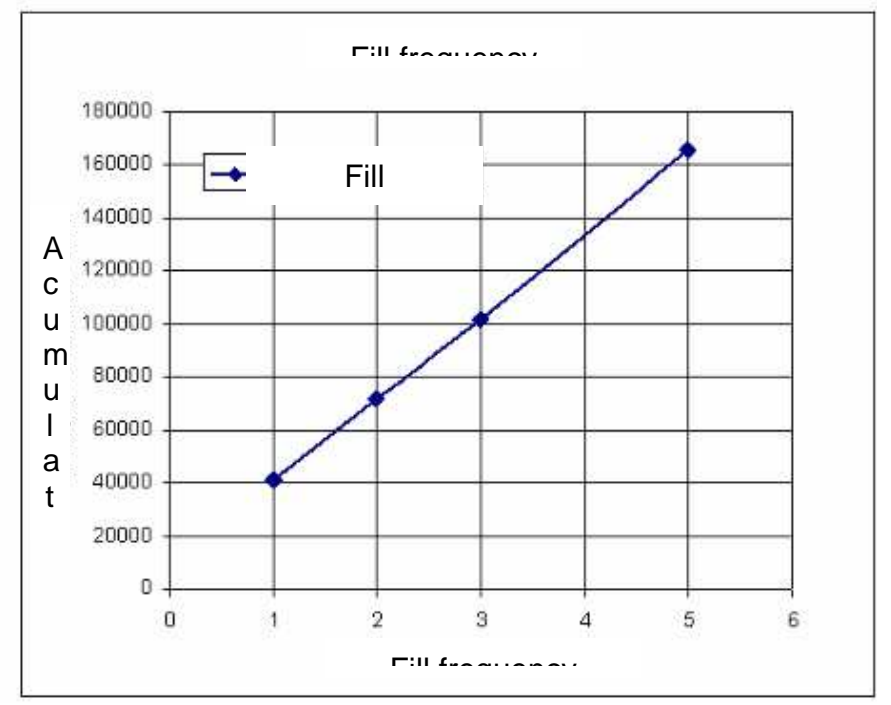

Figure 11.- Alternative A2: Present beach shape, upkeep plan with periodical sand fill

Alternative A3: Beach restoration with two groins and sand filling includes the construction of Porquerola groin and south groin. The total amount of sand in this alternative is $1,620,000 \mathrm{~m}^{3}$. The first groin is $410 \mathrm{~m}$ length and the head reach bathymetric depth of $-8 \mathrm{~m}$. Orientation is N136E. Sand volume retained is $900,000 \mathrm{~m}^{3}$, and the maximum accretion is $145 \mathrm{~m}$. The second one is $390 \mathrm{~m}$ length and reach bathymetric depth of $-8 \mathrm{~m}$. Orientation is N127E. Sand volume retained is $720,000 \mathrm{~m}^{3}$, and maximum accretion is $150 \mathrm{~m}$. In figure 12 a schematic ma is shown.

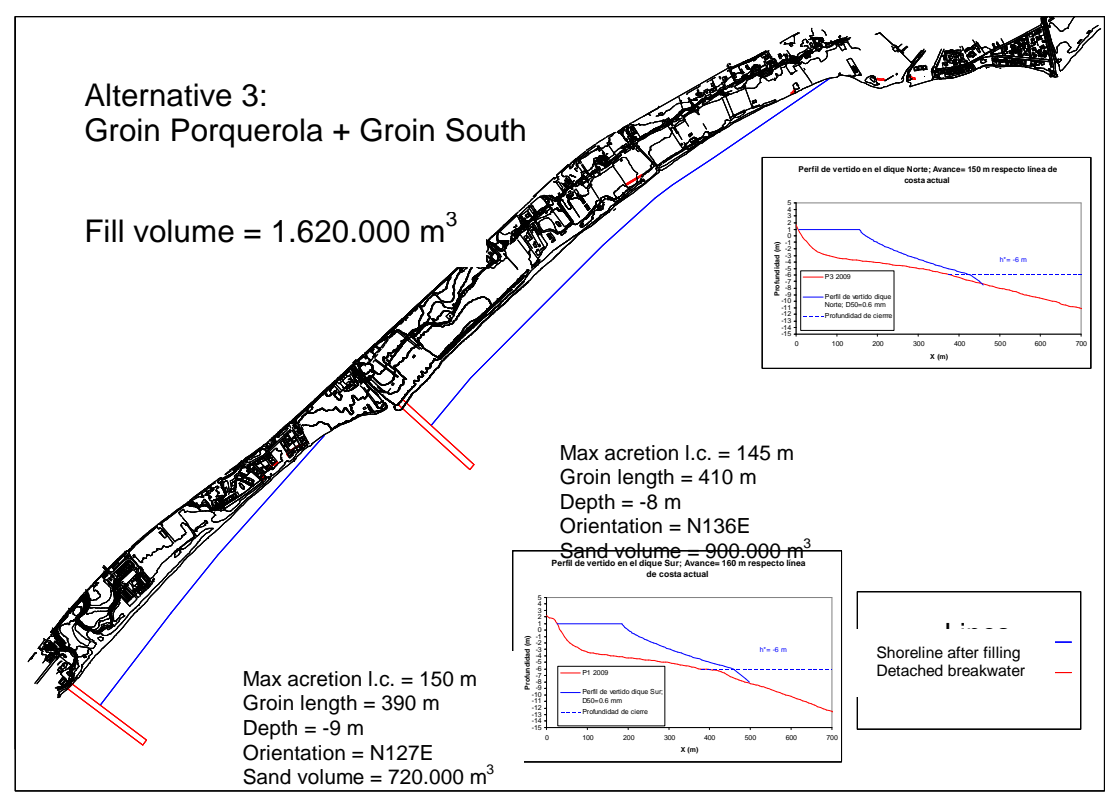

Figure 12.- Alternative A3: Beach restoration with two groins and sand filling 
Alternative A4: Beach restoration with one groin, one detached breakwater (tombolo), and sand filling. This alternative includes the construction of Porquerola detached breakwater (tombolo) and south groin, the total amount of sand in this alternative is $1,890,000 \mathrm{~m}^{3}$ of fill volume. The detached breakwater is $360 \mathrm{~m}$ length and it reaches the bathymetric depth of $-8 \mathrm{~m}$ in the north and $-6.5 \mathrm{~m}$ in the south. Orientation is N54E and shadow area reaches $260 \mathrm{~m}$ to north Porquerola and $560 \mathrm{~m}$ to south, the distance to shoreline is $365 \mathrm{~m}$ in the north and $435 \mathrm{~m}$ in the south. Sand volume retained in the north is $1,100,000 \mathrm{~m}^{3}$. The south groin is $390 \mathrm{~m}$ length and it reach bathymetric depth of $-9 \mathrm{~m}$. Orientation is N127E. Sand volume retained in the south is $790,000 \mathrm{~m}^{3}$ and the maximum accretion $150 \mathrm{~m}$. In figure 13 a schematic map and longshore driven currents, from E waves, are shown.
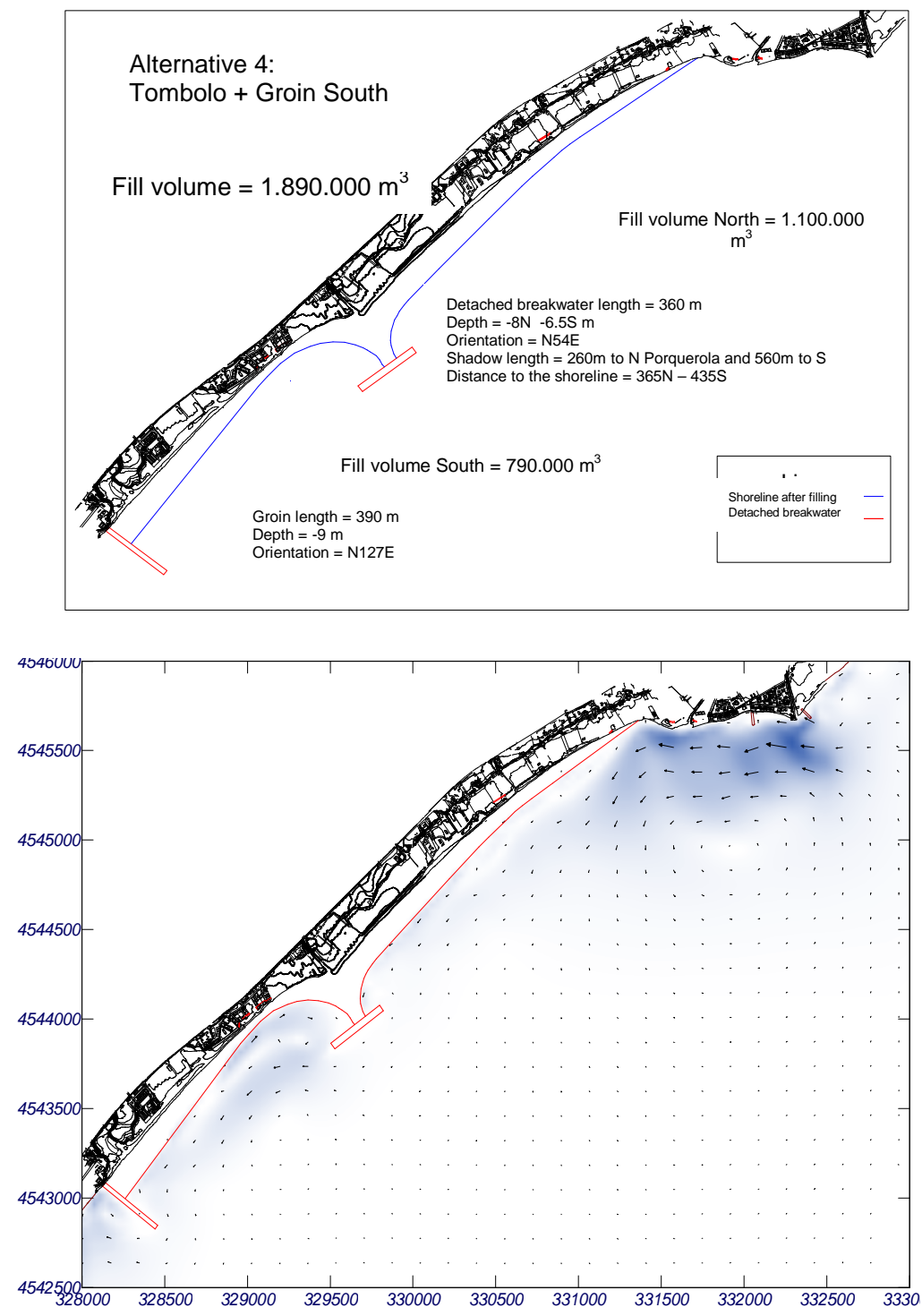

Figure 13.- Alternative A4: Beach restoration with one groin, one detached breakwater (tombolo), and sand filling

Alternative A5: Beach restoration with one groin, one detached breakwater (spit), and sand filling. This alternative includes the construction of Porquerola detached breakwater (spit) and south groin, the total amount of sand in this alternative is $1,830,000 \mathrm{~m}^{3}$ of fill volume. The detached breakwater is 175 $\mathrm{m}$ length and it reaches the bathymetric depth of $-7.5 \mathrm{~m}$ in the north and $-6.5 \mathrm{~m}$ in the south. Orientation is N54E and shadow area reaches $225 \mathrm{~m}$ to north Porquerola and $500 \mathrm{~m}$ to south, the distance to shoreline is $155 \mathrm{~m}$ in the north and $210 \mathrm{~m}$ in the south. Sand volume retained in the north is 1,075,000 $\mathrm{m}^{3}$. The south groin is $390 \mathrm{~m}$ length and it reach bathymetric depth of $-9 \mathrm{~m}$. Orientation is N127E. Sand 
volume retained in the south is $790,000 \mathrm{~m}^{3}$ and the maximum accretion $150 \mathrm{~m}$. In figure 14 a schematic map and longshore driven currents, from $\mathrm{E}$ waves, are shown.
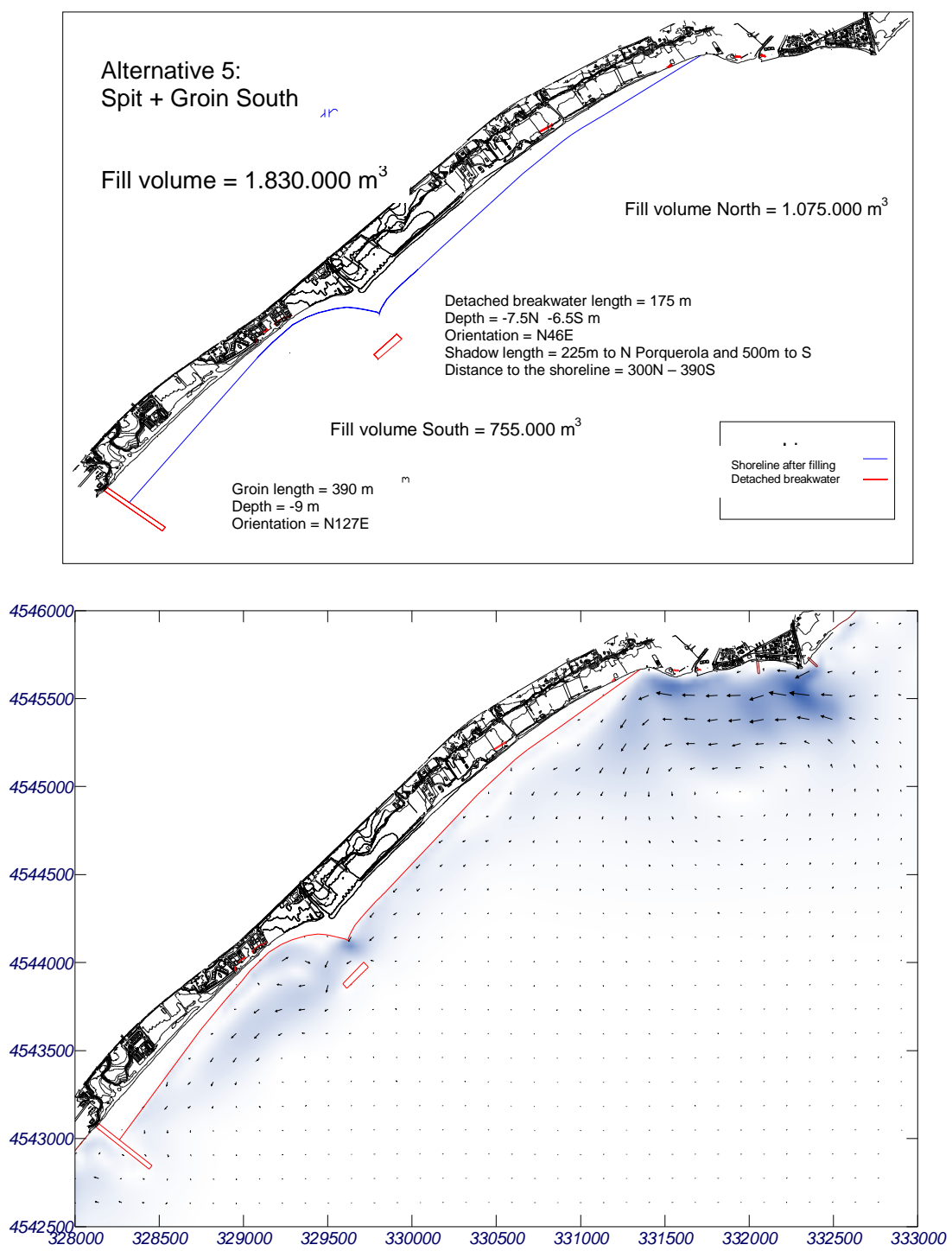

Figure 14.- Alternative A5: Beach restoration with one groin, one detached breakwater (spit), and sand filling

\section{Environmental Aspects}

Several environmental studies have been carried out related with biocenosis and environmental impact assessment. The most important aspect that was investigated was the existence of "posidonia oceanica" and "cymodocea nodosa". A bathymetric, biological, and environmental survey was carried out during the last trimester of 2011. In figure 15, a summary map shows where phanerogam plants are located. These results have incidence in the final solution that will be chosen. These phanerograms are protected species and the location of detached breakwater does not be invasive in these areas. In the next section it can be inferred the incidence on the final solution. 


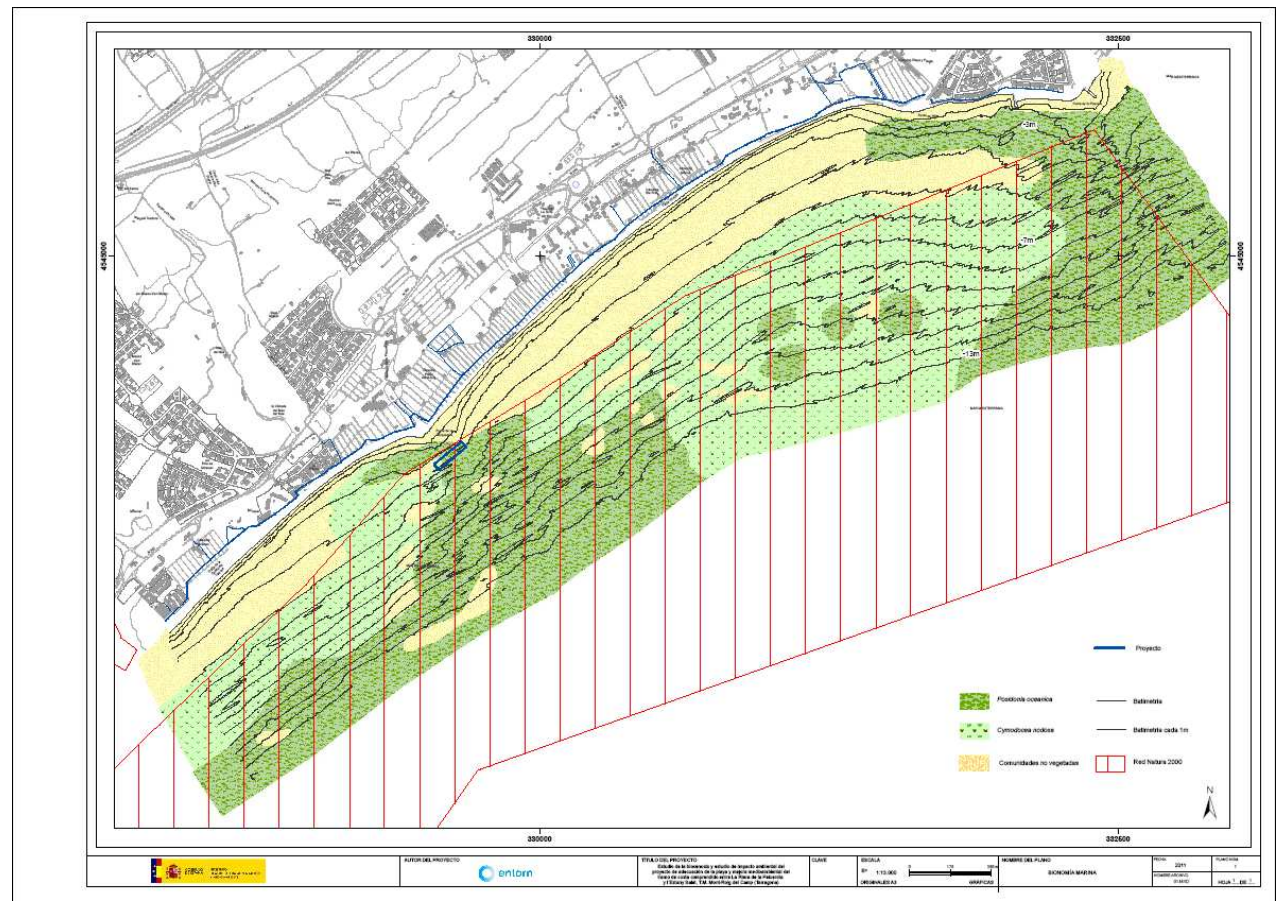

Figure 15.- Phanerogram plants location

\section{CONCLUSIONS}

After this discussion several conclusions will be exposed in order to explain long term beach erosion in Mont-roig del Camp, Taragona, Spain, and how to deal with it.

1.- Coastal stretch from Cambrils to Gelat Marsh has a length about $10 \mathrm{~km}$. Erosion is the main coastal problem in this area, it is focused downdrift Cambrils harbor. This structure interrupts longshore transport decreasing sand filling by the currents in this area. Anthropogenic works and pressure have induced coastal hazards, erosion phenomena.

\section{2.- Erosion causes are:}

- Antropogenic works: Cambrils harbor, detached breakwaters, etc.

- Lack of sediments from streams, gullies, and marshes.

- Shoreline urban pressure.

3.- Waves reach Mont-roig coast from NE/E to W/SW. In medium regimen, waves that generate longshore currents to north and south are similar. In storm conditions, waves that generate longshore current to the south are dominant.

4.- Several alternatives have been proposed in order to mitigate erosion effects:

A1: Natural beach evolution to reach new equilibrium position.

A2: Present beach shape, upkeep plan with periodical sand fill.

A3: Beach restoration with two groins and sand filling.

A4: Beach restoration with one groin, one detached breakwater (tombolo), and sand filling.

A5: Beach restoration with one groin, one detached breakwater (spit), and sand filling.

5.- Biocenosis, biological, and environmental impact assessment were carried out and phanerograms plants ("posidonia oceanica" and "cymodocea nodosa") were located. The existence of them are environment restrictions on detached breakwater location. 
6.- The final alternative proposed is a mixed one between A2 and A5 (only detached breakwater, spit). The location of detached breakwater will be accorded with environmental restrictions, out of phanerogam area.

Alternative proposed A6: Beach restoration with detached breakwater (spit) and upkeep plan with periodical sand fill. The aim of this alternative is to restore the beach to wide of 1956 at the first step. This alternative includes the construction of Porquerola detached breakwater (spit), the total amount of sand to recover 1956 shoreline, in this alternative, is $1,088,000 \mathrm{~m}^{3}$ of fill volume. The detached breakwater is $150 \mathrm{~m}$ length and it reaches the bathymetric depth of $-4 \mathrm{~m}$ in the north and $-4 \mathrm{~m}$ in the south. Orientation is N50E and shadow area reaches $175 \mathrm{~m}$ to north Porquerola and $270 \mathrm{~m}$ to south, the distance to shoreline is $155 \mathrm{~m}$ in the north and $210 \mathrm{~m}$ in the south. The initial sand fill volume needed is: $980,000 \mathrm{~m}^{3}$ initial fill, $8,000 \mathrm{~m}^{3}$ spit accumulation, and $100,000 \mathrm{~m}^{3}$ the first upkeep. Periodical sand fill, every 3 years, is $100,000 \mathrm{~m}^{3}$. In figures 16 and 17 a schematic map and sand accumulation and fill areas, in upkeep works, are shown.

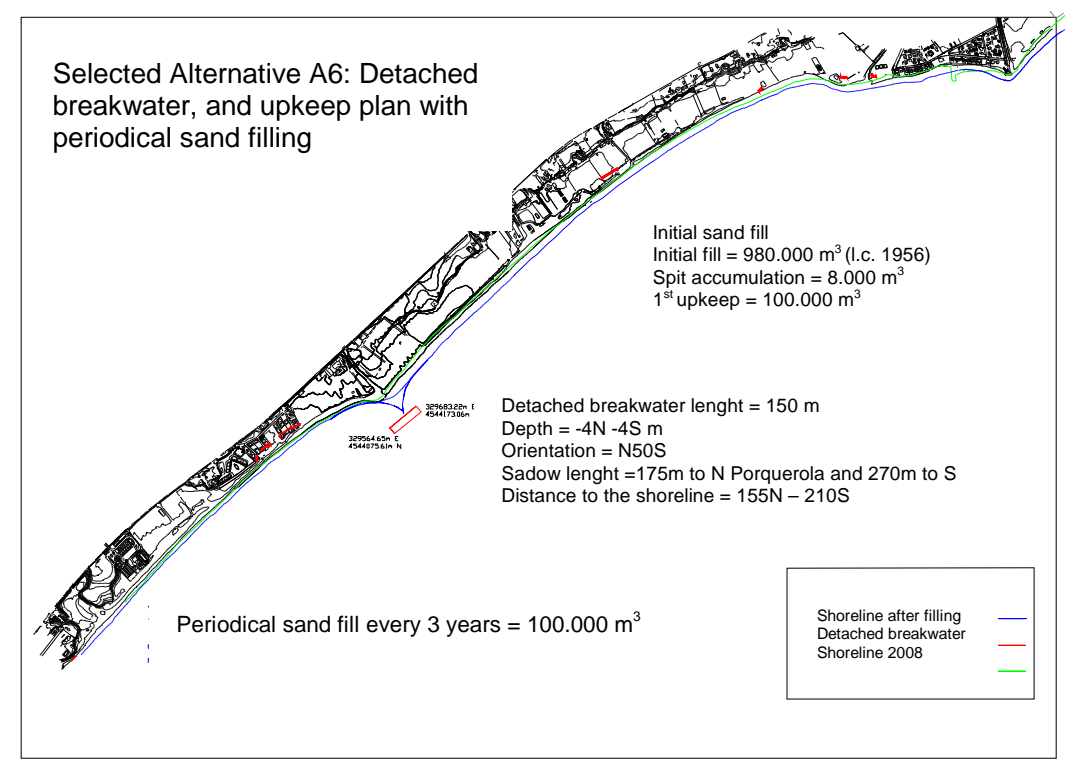

Figure 16.- Alternative A6: Beach restoration with one detached breakwater (spit), and upkeep plan with periodical sand fill
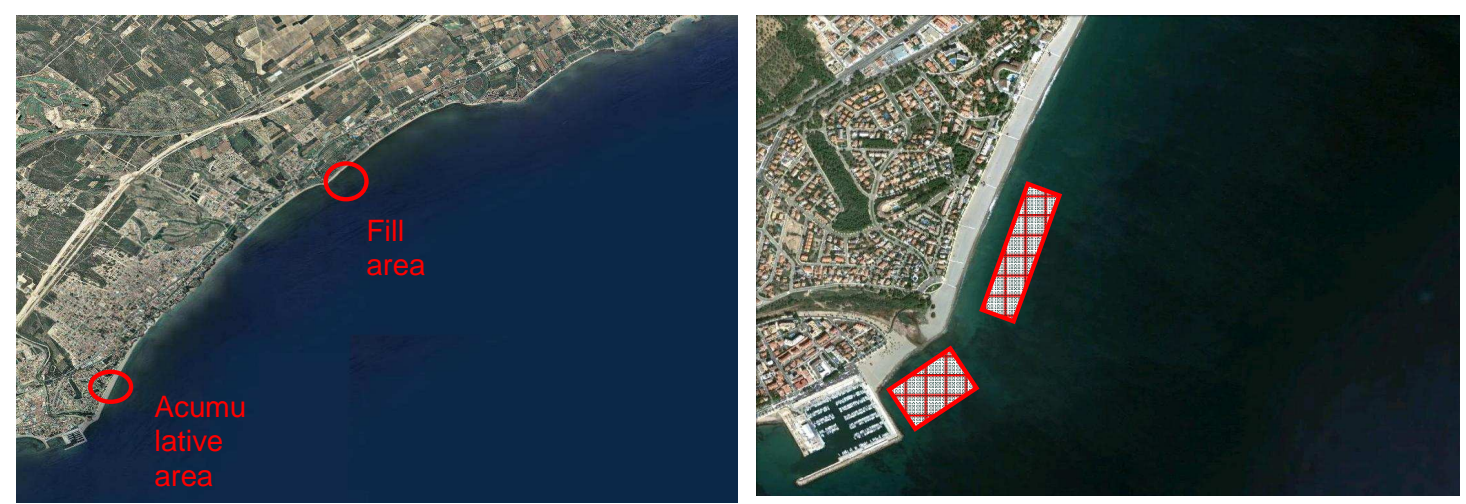

Figure 17.- Sand accumulation and fill areas, in upkeep works. 


\section{REFERENCES}

Galofré, J. y F. Vallespinòs. 1996. Estudio de la biocenosis del frente litoral entre el puerto de Cambrils y la Punta de la Pixerota. TECNOAMBIENTE. Dirección General de Costas, Ministerio de Medio Ambiente.

Galofré, J., G. Ontañón y F. Vallespinòs. 1999. Estudio de impacto ambiental de las obras de regeneración y estabilización del litoral de Tarragona, tramo puerto de Cambrils - la Punta de la Pixerota, y dragado de arena entre Cambrils y L'Ametlla de Mar (Tarragona). INTECSATECNOAMBIENTE. Dirección General de Costas, Ministerio de Medio Ambiente.

Galofré, J. y F. Vallespinòs. 2005. Estudio de impacto ambiental del Proyecto de Dragado de un yacimiento submarino de arenas situado entre Cambrils y L'Ametlla de Mar. TECNOAMBIENTE. Dirección General de Sostenibilidad de la Costa y del Mar, Ministerio de Medio Ambientey Medio Rural y Marino.

Galofré, J., D. Ortiz y P. Pujol. 2012. Estudio de la biocenosis y estudio de impacto ambiental del proyecto de adecuación de la playa y mejora medioambiental del tramo de costa comprendido entre la riera de la Pixerota y l'Estany Gelat, Mont-roig del Camp (Tarragona). ENTORN. Dirección General de Costas, Ministerio de Medio Ambiente.

Medina, R., and L. Vega. 2011. Estudio de Dinámica Litoral de la Playa de Mont-roig del Camp, entre la Riera de la Pixerota y L'Estany Gelat, y Propuesta de Actuaciones de Estabilización de la Misma, Instituto de Hidráulica Ambiental-UC, Dirección General de Sostenibilidad de la Costa y del Mar, Ministerio de Medio Ambiente y Medio Rural y Marino.

Medina, R., and L. Vega. 2012. Adenda al Estudio de Dinámica Litoral de la Playa de Mont-roig del Camp, entre la Riera de la Pixerota y L'Estany Gelat, y Propuesta de Actuaciones de Estabilización de la Misma, Instituto de Hidráulica Ambiental-UC, Dirección General de Sostenibilidad de la Costa y del Mar, Ministerio de Agricultura, Alimentación y Medio Ambiente.

Medina, R., and L. Vega. 2011. Adenda II: Afección de la Actuación Propuesta a la "Posidonia Oceanica", Estudio de Dinámica Litoral de la Playa de Mont-roig del Camp, entre la Riera de la Pixerota y L'Estany Gelat, y Propuesta de Actuaciones de Estabilización de la Misma, Instituto de Hidráulica Ambiental-UC, Dirección General de Sostenibilidad de la Costa y del Mar, Ministerio de Medio Ambiente y Medio Rural y Marino. 